\title{
Ternary complexation of carvedilol, $\beta$-cyclodextrin and citric acid for mouth-dissolving tablet formulation
}

\author{
VARSHA POKHARKAR* \\ ABHISHEK KHANNA \\ VINOD VENKATPURWAR \\ SHEETAL DHAR \\ LEENATA MANDPE \\ Department of Pharmaceutics \\ Bharati Vidyapeeth University \\ Poona College of Pharmacy \\ Erandwane, Pune-411038 \\ Maharashtra, India
}

\begin{abstract}
The purpose of this study was to improve the solubility and dissolution rate of carvedilol by forming a ternary complex with $\beta$-cyclodextrin and citric acid and to formulate its mouth-dissolving tablets. The rationale for preparing mouth-dissolving tablet of carvedilol was to make the drug available in a soluble form in the mouth, which would facilitate its absorption from the buccal cavity. This would help to overcome its first-pass metabolism and thereby improve bioavailability. Phase solubility studies revealed the ability of $\beta$-cyclodextrin and citric acid to complex with carvedilol and significantly increase its solubility. Ternary complexation of carvedilol was carried out with $\beta$-cyclodextrin and citric acid by physical mixing, kneading and spray drying methods and the prepared complexes were characterized by Fourier transform infra red spectroscopy, differential scanning calorimetry, powder X-ray diffractometry, scanning electron microscopy and complexation efficiency. The complex obtained by the spray drying method resulted in highest complexation efficiency and a 110-fold increase in the solubility of carvedilol. The mouth-dissolving tablets formulated using the spray dried complex with suitable excipients showed $100 \%$ dissolution within five minutes. Accelerated stability studies of mouth-dissolving tablets carried out as per ICH guidelines revealed that the tablets were stable.
\end{abstract}

Keywords: carvedilol, cyclodextrin, citric acid, ternary complex, solubility, spray drying, mouth-dissolving tablet

Carvedilol is a non-selective beta-blocker indicated in the treatment of mild to moderate congestive heart failure. It is a basic, lipophilic compound. Being categorized as Class II compound as per the BCS classification system, it possesses very poor oral bioavailability and shows significant first pass metabolism (1). Thus, a strategy to improve bioavailability should aim at improving its aqueous solubility and overcoming first pass

* Correspondence; e-mail: vbpokharkar@yahoo.co.in 
metabolism. Innovative drug delivery systems known as »melt in mouth « or »mouth dissolve tablets « are novel types of tablets that disintegrate/disperse/dissolve in saliva. Their characteristic advantage, such as administration without water anywhere anytime, leads to their suitability for geriatric and pediatric patients. They are also most suitable for drugs that undergo extensive fist pass metabolism. The benefits, in terms of patient compliance, rapid onset of action as the drug goes directly into systemic circulation and good stability, make these tablets popular as a dosage form of choice on the current market. However, a major challenge is to develop mouth-dissolving tablets of poorly soluble drugs (2).

Of the various approaches to improve drug solubility, complexation with cyclodextrin is being widely explored. Cyclodextrins are powerful carriers for improving the therapeutic efficacy of drugs with poor aqueous solubility through inclusion complexes. However, exploitation of this cyclodextrin property is hindered by the relatively low water solubility and high molecular mass of natural cyclodextrin $(3,4)$. Among the strategies proposed for this aim, addition of suitable auxiliary substances can be a valuable approach to increase the cyclodextrin solubilization capacity. It has been reported that certain low molecular mass acids or hydroxyl acids e.g., citric acid, tartaric acid, can strongly enhance the cyclodextrin solubilizing power towards basic drugs as a result of the combined effect of salt formation and inclusion complexation $(5,6)$.

The purpose of this study was to investigate a dual approach by forming an inclusion complex along with an appropriate salt form of carvedilol in order to improve its aqueous solubility and dissolution rate.

\section{EXPERIMENTAL}

\section{Materials}

Carvedilol was a generous gift from M/s Symed Labs (India). $\beta$-cyclodextrin was purchased from M/s ISP Ltd. (Hong Kong). Citric acid, potassium dihydrogen phosphate, sodium hydroxide, calcium chloride were supplied by M/s Merck Ltd. (India). All other reagents and solvents used were of analytical grade.

\section{Analysis of carvedilol using a UV-visible spectrophotometer}

First, $100 \mu \mathrm{g} \mathrm{mL}^{-1}$ stock solution of carvedilol was prepared in methanol and further dilutions were made in distilled water ranging from 5-30 $\mu \mathrm{g} \mathrm{mL}^{-1}$. The calibration curve was obtained by recording the absorbance on a UV spectrophotometer (Jasco V350, Japan) at $285 \mathrm{~nm}$ (7). Linearity in the calibration curve was observed with regression $R^{2}=0.9995$.

\section{Phase solubility studies with $\beta$-cyclodextrin}

An excess of drug was added to $10 \mathrm{~mL}$ of $\beta$-cyclodextrin aqueous solution (1-5 $\mathrm{mmol} \mathrm{L}-1$ ) in a stoppered conical flask and shaken at room temperature on a magnetic stirrer. At equilibrium after 2 days, aliquots were withdrawn, centrifuged at $4000 \mathrm{rpm}$ 
V. Pokharkar et al.: Ternary complexation of carvedilol, $\beta$-cyclodextrin and citric acid for mouth-dissolving tablet formulation, Acta Pharm. 59 (2009) 121-132.

for 10 minutes, filtered $(0.22-\mu \mathrm{m}$ pore size, Whatman, UK) and spectrophotometrically assayed for drug content at $285 \mathrm{~nm}$.

\section{Phase solubility studies with $\beta$-cyclodextrin and citric acid}

An excess of drug was added to $10 \mathrm{~mL}$ aqueous solution containing citric acid (1-4 mmol L-1) and $2 \mathrm{mmol} \mathrm{L}^{-1}$ of $\beta$-cyclodextrin in a stoppered conical flask and shaken at room temperature on a magnetic stirrer. At equilibrium after 2 days, aliquots were withdrawn, centrifuged at $4000 \mathrm{rpm}$ for 10 minutes, filtered $(0.22-\mu \mathrm{m}$ pore size, Whatman) and spectrophotometrically assayed for drug content at $285 \mathrm{~nm}$.

\section{Preparation of ternary complexes}

Carvedilol, $\beta$-cyclodextrin and citric acid ternary complexes were prepared at 1:2:2 molar ratios, respectively, as described in detail below.

Physical mixture (PM). - For physical mixtures, carvedilol, $\beta$-cyclodextrin and citric acid were weighed accurately, mixed thoroughly by trituration in a mortar and sieved through a $0.25-\mathrm{mm}$ sieve. All physical mixtures were stored in a dessicator until further evaluation.

Kneaded complex (KC). - The kneaded complex of carvedilol, $\beta$-cyclodextrin and citric acid was prepared by wetting the physical mixture in a mortar with a minimum volume of ethanol/water mixture $(15 / 85, V / V)$ and kneading thoroughly with a pestle to obtain a paste, which was then dried under vacuum at room temperature, sieved through a $0.25-\mathrm{mm}$ sieve and stored in a dessicator until further evaluation.

Spray dried complex (SDC). - A mixture of carvedilol, $\beta$-cyclodextrin and citric acid was dissolved in ethanol/water $(15 / 85, V / V)$. The resultant clear solution was kept for stirring on a magnetic stirrer for 48 hours at room temperature so as to attain complexation equilibrium. Spray drying was carried out using a laboratory scale spray dryer (Jay Instruments and System Pvt. Ltd., India) under the following set of conditions: inlet temperature $112{ }^{\circ} \mathrm{C}$, outlet temperature $55^{\circ} \mathrm{C}$, atomization air pressure $100 \mathrm{kPa}$, aspiration pressure $-2.5 \mathrm{kPa}$, flow rate $12 \mathrm{~mL} \mathrm{~min}{ }^{-1}$. The powder sample was sieved through a $0.25-\mathrm{mm}$ sieve and stored in a dessicator until further evaluation.

\section{Estimation of free and complexed drug}

The inclusion yield of complexes was determined by dissolving $10 \mathrm{mg}$ of the complex in $10 \mathrm{~mL}$ anhydrous acetonitrile for estimation of free drug and another $10 \mathrm{mg}$ of complex in $10 \mathrm{~mL}$ acetonitrile/water solution (1:1) for estimation of total drug. The solutions were centrifuged at $4000 \mathrm{rpm}$ for 10 minutes, filtered $(0.22-\mu \mathrm{m}$ pore size, Whatman) and spectrophotometrically assayed for drug content at $285 \mathrm{~nm}$.

\section{Differential scanning calorimetry (DSC)}

DSC studies were carried out using differential scanning calorimetry equipped with an intracooler (DSC 821e, Mettler Toledo, Switzerland). Indium/zinc standards were used 
V. Pokharkar et al.: Ternary complexation of carvedilol, $\beta$-cyclodextrin and citric acid for mouth-dissolving tablet formulation, Acta Pharm. 59 (2009) 121-132.

to calibrate the DSC temperature and enthalpy scale. The drug and drug complex were hermetically sealed in aluminum pans and heated at a constant rate of $10{ }^{\circ} \mathrm{C} \mathrm{min}-1$ over a temperature range of 25 to $225^{\circ} \mathrm{C}$; inert atmosphere was maintained by purging nitro-

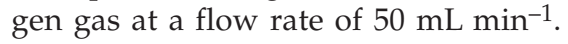

\section{Powder X-ray diffractometry (PXRD)}

PXRD patterns were recorded on an X-ray diffractometer (PW 1729, Philips, The Netherlands). The samples were irradiated with monochromatized $\mathrm{Cu}-\mathrm{k}_{\infty}$ radiation and analyzed between 2 to $70^{\circ} \theta$. The voltage and current used were $30 \mathrm{kV}$ and $30 \mathrm{~mA}$, respectively.

\section{Scanning electron microscopy (SEM)}

Samples were coated with a thin gold-palladium layer using a sputter coater unit (VG-Microtech, UK) and the surface topography was analyzed with a Cambridge Stereoscan 120 scanning electron microscope (SEM, Cambridge, UK) operated at an acceleration voltage of $15 \mathrm{kV}$.

\section{Fourier transform infrared spectroscopy (FTIR)}

FTIR spectroscopy was performed on a Fourier Transform Infrared Spectrometer (JASCO, V 5300, Japan). Pellets of the drug sample in $\mathrm{KBr}$ were prepared on $\mathrm{KBr}$ press (Spectra $\mathrm{Lab}$, India). The spectra were scanned over a wavenumber range of 4000 to $400 \mathrm{~cm}^{-1}$.

\section{Saturation solubility of the complex}

Saturation solubility of the complexes was determined by equilibrating an excess of complex in different media such as $0.1 \mathrm{~mol} \mathrm{~L}^{-1} \mathrm{HCl}(\mathrm{pH} 1.2)$, acetate buffer ( $\left.\mathrm{pH} 4.5\right)$, simulated saliva ( $\mathrm{pH}$ 6.2), and distilled water for 48 hours on a mechanical shaker at room temperature. At equilibrium after 2 days, aliquots were withdrawn, followed by centrifugation at $4000 \mathrm{rpm}$ for 10 minutes, filtration $(0.22-\mu \mathrm{m}$ pore size, Whatman $)$ and a spectrophotometric assay for drug content at $285 \mathrm{~nm}$.

\section{Preparation of mouth-dissolving tablets}

All formulations of pure carvedilol or carvedilol complex (equivalent to $6.25 \mathrm{mg}$ of carvedilol) were compressed into tablets using a 10-station, single rotary, B-tooling tablet machine (M/s Rimek Tabletting Machine, MINI PRESS-I, B-tooling, Karnawati Engineering Ltd, India) using a flat face bevel edged 11-mm die and punch set. Tabletting excipients such as lactose monohydrate, microcrystalline cellulose (Avicel pH 102), mannitol, saccharine, crosspovidone (super disintegrant) or magnesium stearate were added as per the composition given in Table I. Tablets were prepared by the wet granulation method using water as a granulating agent. The prepared tablets were evaluated for mass variation, hardness, friability, content uniformity, disintegration time and in vitro dissolution. 
V. Pokharkar et al.: Ternary complexation of carvedilol, $\beta$-cyclodextrin and citric acid for mouth-dissolving tablet formulation, Acta Pharm. 59 (2009) 121-132.

Table I. Composition of carvedilol complex tablets

\begin{tabular}{clc}
\hline Sample No. & \multicolumn{1}{c}{ Component } & Mass per tablet $(\mathrm{mg})$ \\
\hline & Intragranular portion & \\
\hline 1 & Ternary complex obtained by spray drying & 56.81 \\
2 & $(6.25$ mg carvedilol) & 25.18 \\
3 & Lactose & 27.00 \\
4 & Microcrystalline cellulose & 20.00 \\
5 & Mannitol & 2.00 \\
6 & Saccharine & 4.00 \\
7 & Crospovidone & q.s. \\
\hline & Water (granulating solution) & 6.00 \\
\hline & Extragranular portion & 2.00 \\
\hline
\end{tabular}

\section{In vitro dissolution studies}

Dissolution studies were performed using a USP 27 (8) type II dissolution test apparatus (TDT-06P, Electrolab, India) in distilled water. Tablets of different formulations were placed in a dissolution vessel containing $900 \mathrm{~mL}$ medium maintained at $37 \pm 0.5^{\circ} \mathrm{C}$ and stirred at $50 \mathrm{rpm}$. Samples were collected periodically and were replaced with fresh dissolution medium. Collected samples were filtered through Whatman filter paper. Concentration of carvedilol was determined spectrophotometrically at $285 \mathrm{~nm}$.

\section{Stability studies}

The accelerated stability study of prepared tablets was carried out as per ICH guidelines at $40{ }^{\circ} \mathrm{C} / 75 \% \mathrm{RH}$ for up to 3 months. Samples were removed and evaluated for mass variation, hardness, friability, content uniformity, disintegration time, dissolution, PXRD and DSC studies.

\section{RESULTS AND DISCUSSION}

\section{Phase solubility studies}

The phase-solubility diagram for complex formation between carvedilol and $\beta$-cyclodextrin is presented in Fig. 1. According to the Higuchi and Connors classification (9), the diagram shows the $A_{N}$ type curve where the solubility increases linearly with cyclodextrin concentration and further deviates negatively at higher cyclodextrin concentrations. The interaction mechanism for the $A_{N}$ type curve is complicated because of a significant contribution of solute-solvent interaction to the complexation. The negative 


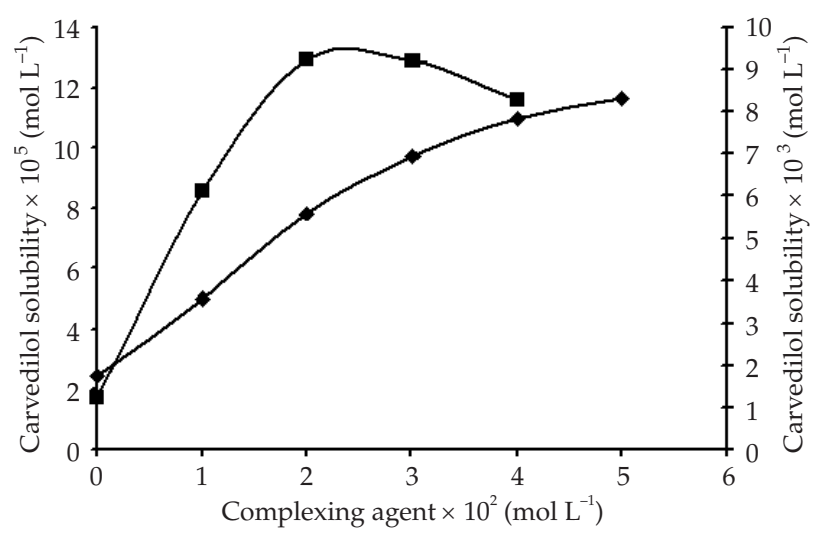

Fig. 1. Phase solubility diagram of carvedilol in solutions containing: a) varying contretation of $\beta$-cyclodextrin $(\checkmark)$ and varying concentration of citric acid containing $2 \mathrm{mmol} \mathrm{L}^{-1}$ of $\beta$-cyclodextrin (ם).

deviation from linearity may be associated with cyclodextrin induced changes in the dielectric constant of the aqueous complexation media, changes in complex solubility or self-association of cyclodextrin molecules. It can be seen from the curve, that the apparent solubility of carvedilol increased linearly due to the formation of a soluble inclusion complex between carvedilol and $\beta$-cyclodextrin. Earlier Wen et al. (10) reported a similar $A_{N}$ type curve and further concluded from the fluorescence study that carvedilol forms a 1:2 complex with $\beta$-cyclodextrin.

The phase solubility diagram of carvedilol with $\beta$-cyclodextrin and citric acid (Fig. 1 ) illustrates the $A_{N}$ type of curve. The addition of citric acid along with $\beta$-cyclodextrin resulted in an increase in solubility of carvedilol to a much greater extent compared to complexation of the drug with $\beta$-cyclodextrin alone. This may be attributed to the fact that organic hydroxyl acids such as citric acid are able to enhance the solubility of the basic guest molecule both by forming a salt and by increasing the stability constant of the complex (11). Thus the addition of citric acid results in formation of carvedilol citrate salt (6).

\section{Estimation of free and complexed drug content}

The complexation efficiency, i.e., the inclusion yield of the drug in $\beta$-cyclodextrin was determined based on the differential solubility of free drug and complexed drug (12). The amount of complexed drug was the highest in the case of the complex obtained by the spray drying method $(83.2 \pm 0.6 \%)$ compared to the kneaded complex $(68.7 \pm 1.1$ $\%)$ and physical mixture $(3.4 \pm 1.0 \%)(n=3)$. This indicated that the drug in the physical mixture remained essentially in the un-complexed form. Hence, complexation by spray drying was found to be a highly efficient method to produce the carvedilol- $\beta$-cyclodextrin-citric acid ternary complex.

\section{Differential scanning calorimetry}

DSC was used to identify the inclusion ternary complex between the drug, $\beta$-cyclodextrin and citric acid. As seen from Fig. 2a, the DSC thermogram of carvedilol alone 
showed a sharp endothermic peak at $118^{\circ} \mathrm{C}$, corresponding to the melting point of the crystalline form of carvedilol. The physical mixture showed separate endotherms corresponding to carvedilol $\left(118{ }^{\circ} \mathrm{C}\right)$, citric acid $\left(75-80^{\circ} \mathrm{C}\right)$ and $\beta$-cyclodextrin, indicating no complex formation. In case of the kneaded complex, a broad endotherm was obtained around $120^{\circ} \mathrm{C}$. The thermogram of the inclusion ternary complex prepared by the spray drying method shifted towards lower temperature showed a broad endotherm between 90 and $100{ }^{\circ} \mathrm{C}$. Lower temperature of the inclusion ternary complex can be attributed to the melting point depression in the complex. Similar conditions were found when felodipine and carbamazepine were complexed with $\beta$-cyclodextrin, which resulted in the lowering of the endothermic peak of the complexed drug (13). Also in the case of the
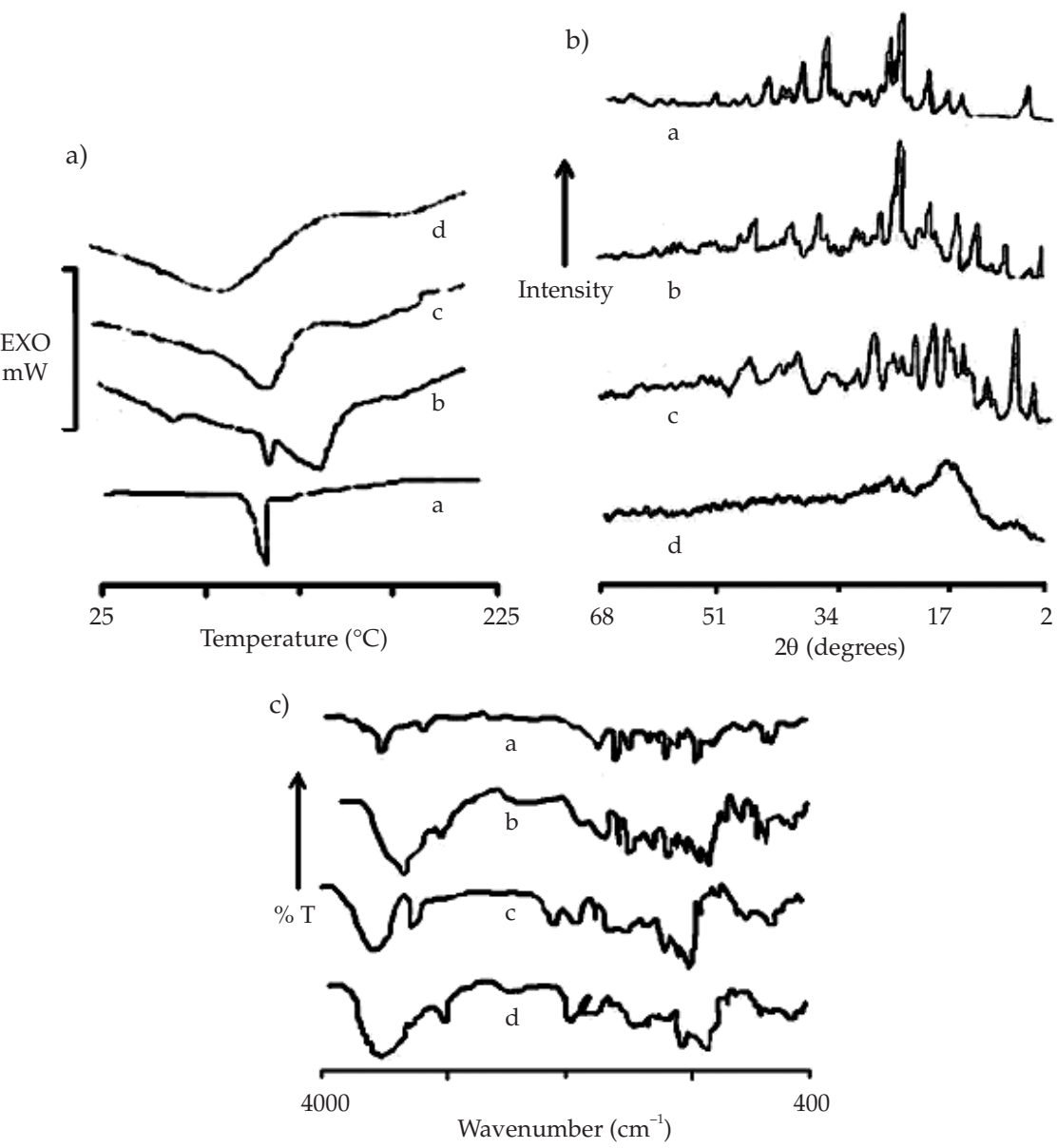

Fig. 2. a) Differential scanning calorimetry, b) X-Ray powder diffraction patterns and c) FT-IR spectra of: $a$ - pure drug, $b$ - physical mixture, $c$ - complex obtained by kneading, $d$ - complex obtained by spray drying. 
complex obtained by spray drying, it can be concluded that amorphization of the drug occurred in the presence of $\beta$-cyclodextrin and citric acid and trapping of carvedilol inside the $\beta$-cyclodextrin cavity, leading to the broad nature of the endotherm.

\section{Powder X-ray diffractometry}

The PXRD graphs for pure drug, physical mixture, kneaded complex and complex obtained by sprey drying are shown in Fig. 2b. Peaks for crystallinity were observed in pure drug at $2 \theta$ values of $6,12,14,15,18.5,25,27$ and $28^{\circ}$. The PXRD of complexes prepared by physical mixing and kneading revealed the presence of the uncomplexed crystalline nature of the drug. However, it was interesting to note that these peaks were suppressed or absent in the complex obtained by spraying drying indicating amorphization of the drug and complexation of carvedilol with $\beta$-cyclodextrin. These results of PXRD were strongly supported by the above DSC observations.

\section{Fourier transform infrared spectroscopy}

Fig. 2c shows the infrared spectra of pure drug, physical mixture, kneaded complex and ternary complex obtained by spray drying. Carvedilol showed characteristic peaks at $3346.8 \mathrm{~cm}^{-1}\left(\mathrm{O}-\mathrm{H}\right.$ and $\mathrm{N}-\mathrm{H}$ stretching vibration peaks merged together), $2924.35 \mathrm{~cm}^{-1}$ (C-H stretching vibrations), $1591.42 \mathrm{~cm}^{-1}$ (N-H bending vibrations) and $1255.77 \mathrm{~cm}^{-1}$ (O-H bending and $\mathrm{C}-\mathrm{O}$ stretching vibrations). The intensity and shape of these bands changed dramatically for the inclusion ternary complex compared to the physical mixture and pure drug. The complex showed broadening of $\mathrm{O}-\mathrm{H}$ and $\mathrm{N}-\mathrm{H}$ stretching vibrations peaks $\left(3383.45 \mathrm{~cm}^{-1}\right)$. Differences were found in the $1480-1600 \mathrm{~cm}^{-1}$ region, which were attributed to skeleton vibrations of the $\mathrm{C}=\mathrm{C}$ bonds in the aromatic ring. In the low frequency region (1000-400 $\left.\mathrm{cm}^{-1}\right)$, all the spectra were almost unchanged, indicating that overall symmetry of the molecule was not significantly affected even though the vibration and bending of the drug were restricted due to the formation of an inclusion complex.

\section{Scanning electron microscopy}

The microphotographs of pure drug, kneaded and spray dried ternary complex are shown in Fig. 3. The pure drug appeared to be in the crystalline form. In case of the ternary complex obtained by spray drying, significant changes in particle shape and surface topography were observed. Particles appeared as irregularly shaped agglomerates

a)

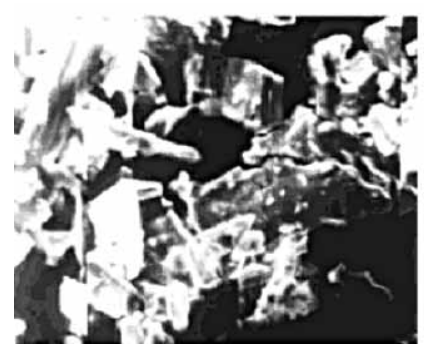

b)

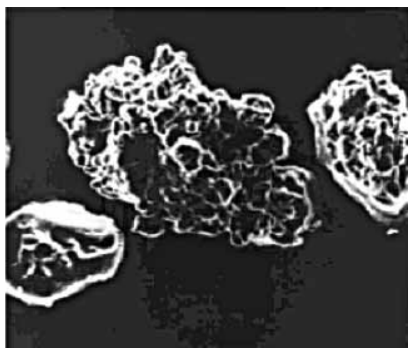

Fig. 3. Scanning electron microscope photographs: a) pure drug, b) complex obtained by spray drying. 
V. Pokharkar et al.: Ternary complexation of carvedilol, $\beta$-cyclodextrin and citric acid for mouth-dissolving tablet formulation, Acta Pharm. 59 (2009) 121-132.

Table II. Saturation solubility

\begin{tabular}{lcccc}
\hline Solvent & $\begin{array}{c}\text { Pure drug } \\
\left(\mathrm{mg} \mathrm{mL}^{-1}\right)^{\mathrm{a}}\end{array}$ & $\begin{array}{c}\text { Physical } \\
\text { mixture } \\
\left(\mathrm{mg} \mathrm{mL}^{-1}\right)^{\mathrm{a}}\end{array}$ & $\begin{array}{c}\text { Ternary complex } \\
\text { obtained by knead- } \\
\text { ing }\left(\mathrm{mg} \mathrm{mL}^{-1}\right)^{\mathrm{a}}\end{array}$ & $\begin{array}{c}\text { Ternary complex } \\
\text { obtained by spray } \\
\text { drying }\left(\mathrm{mg} \mathrm{mL}^{-1}\right)^{\mathrm{a}}\end{array}$ \\
\hline Distilled water & $0.008 \pm 0.003$ & $0.092 \pm 0.019$ & $0.650 \pm 0.090$ & $0.927 \pm 0.060$ \\
$\mathrm{HCl}(\mathrm{pH} \mathrm{1.2)}$ & $0.567 \pm 0.028$ & $0.548 \pm 0.009$ & $0.580 \pm 0.075$ & $0.614 \pm 0.033$ \\
Acetate buffer (pH 4.5) & $0.707 \pm 0.044$ & $0.826 \pm 0.423$ & $1.048 \pm 0.016$ & $1.329 \pm 0.126$ \\
Simulated saliva (pH 6.2) & $0.074 \pm 0.003$ & $0.076 \pm 0.003$ & $0.258 \pm 0.092$ & $0.433 \pm 0.011$ \\
\hline
\end{tabular}

a Mean $\pm \mathrm{SD}, n=3$.

with surface smoothness indicating an amorphous nature. These results support the PXRD and DSC studies.

\section{Saturation solubility of complexes}

Saturation solubility of the pure drug and complexed drug prepared by different methods in different buffer media is shown in Table II. Carvedilol is almost insoluble in water, with saturation, solubility of $(8.5 \pm 2.6) \times 10^{-3} \mathrm{mg} \mathrm{mL}^{-1}$. A significant increase (110-fold) in solubility in distilled water was obtained in the case of the ternary complex obtained by spray drying. This may be attributed to the formation of the ternary complex of the drug with $\beta$-cyclodextrin and citric acid. Also, the spray-drying method has greater efficiency for inclusion complex formation than the kneading method. It also resulted in the amorphous nature of the complex, as evidenced in DSC, PXRD and SEM studies. The saturation solubility of the spray dried drug was also determined and found to be $(9.2 \pm 1.9) \times 10^{-3} \mathrm{mg} \mathrm{mL}^{-1}$. Thus, mere spray drying of the drug does not bring about an increase in solubility of the drug as obtained in the case of the ternary complex obtained by spray drying.

\section{Physical properties and dissolution of tablets}

The tablets containing pure drug and the ternary complex obtained by kneading and spray drying were prepared using the wet granulation technique. Tablets were analyzed for mass variation, friability, disintegration time and drug content (Table III). The in vitro drug dissolution studies of the tablet with complexed carvedilol obtained by

Table III. Physical properties of tablets

\begin{tabular}{lccccc}
\hline \multicolumn{1}{c}{$\begin{array}{c}\text { Sample } \\
\text { No. }\end{array}$} & $\begin{array}{c}\text { Mass } \\
(\mathrm{mg})^{\mathrm{a}}\end{array}$ & $\begin{array}{c}\text { Hardness } \\
(\mathrm{N})^{\mathrm{a}}\end{array}$ & $\begin{array}{c}\text { Friability } \\
(\%)\end{array}$ & $\begin{array}{c}\text { Disintegration time } \\
(\mathrm{s})\end{array}$ & $\begin{array}{c}\text { Drug } \\
(\%)\end{array}$ \\
\hline $\begin{array}{l}\text { Pure drug } \\
\begin{array}{l}\text { Complex obtained } \\
\text { by spray drying }\end{array}\end{array}$ & $151.7 \pm 1.1$ & $40.2 \pm 2.2$ & 0.719 & 22 & $102.7 \pm 1.5$ \\
\hline
\end{tabular}

a Mean \pm SD, $n=3$. 


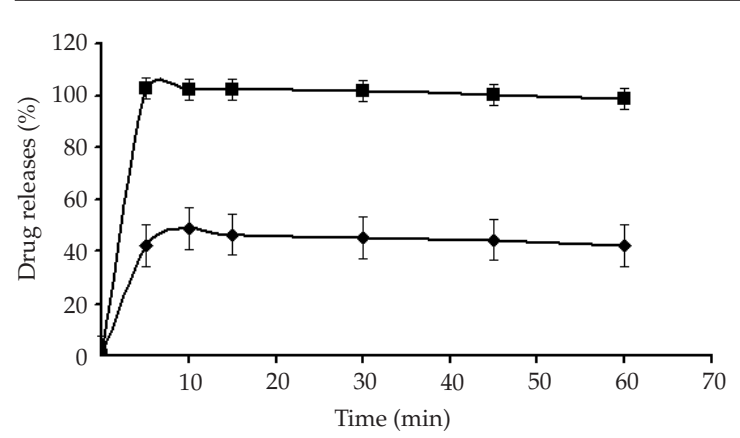

Fig. 4. Dissolution profile of the pure drug tablet $(\diamond)$ and the tablet with complex obtained by spray drying (घ) (mean $\pm \mathrm{SD}, n=6)$.

spray drying and pure carvedilol tablet were carried out in distilled water (shown in Fig. 4). A significant improvement in the dissolution profile of tablets prepared from the carvedilol complex was observed as compared to the pure drug tablet. 100 and $30 \%$ release, resp. was obtained in 5 minutes in the case of tablets with the complex and pure drug tablets. These results support the saturation solubility study. Since $100 \%$ drug release was achieved in 5 minutes this makes it suitable as a mouth-dissolving tablet.

\section{Stability study}

Stability studies were carried out for the tablets with the complex obtained by spray drying by exposing them to $40{ }^{\circ} \mathrm{C}$ at $75 \%$ relative humidity. Drug content, disintegration time, dissolution, XRD and DSC studies were carried out at the end of 3 months and compared to the day zero. No significant changes were observed in drug content, dissolution and disintegration of the tablet with the complex obtained by spray drying after 3 months.

Also, the PXRD and DSC patterns of the complex powder obtained by spray drying recorded after 3 months gave identical patterns (data not shown) to the initial ones.

\section{CONCLUSIONS}

Phase solubility studies of carvedilol with $\beta$-cyclodextrin showed that the $A_{N}$ type of curve was obtained, which indicated that the complex was formed in a 1:2 molar ratio. Phase solubility of the drug with $\beta$-cyclodextrin and citric acid showed higher solubilization efficiency. The ternary complex of carvedilol- $\beta$-cyclodextrin-citric acid was formed in a molar ratio of 1:2:2. Preparation of carvedilol- $\beta$-cyclodextrin-citric acid ternary complex by spray drying resulted in effective complexation with significant improvement in aqueous solubility compared to the physical mixture and kneaded complex. The in vitro dissolution studies of the tablets prepared from the ternary complex of carvedilol obtained by spray drying showed $100 \%$ release in 5 minutes. In the stability study, no significant changes were recorded with respect to XRD, DSC, drug content, disintegration and dissolution over a period of 3 months, indicating a stable complex. Since $100 \%$ release of the drug from the tablet was obtained within 5 minutes, the approach is suitable for the formulation of mouth-dissolving tablets of carvedilol. 


\section{REFERENCES}

1. N. Kasim, M. Whitehouse, C. Ramchandran, M. Bermejo, H. Lennernas, A. S. Hussain, H. E. Junginger, S. A. Stavchansky, K. K. Midha, V. P. Shah and G. L. Amidon, Molecular properties of WHO essential drugs and provisional biopharmaceutical classification, Mol. Pharm. 1 (2004) 85-96; DOI: 10.1021/mp034006h.

2. M. Gohel, M. Patel, A. Amin, R. Agrawal, R. Dave and N. Bariya, Formulation design and optimization of mouth dissolve tablets of nimesulide using vacuum drying technique, AAPS PharmSciTech. 36 (2004) 1-6.

3. T. Loftsson, D. Hreinsdottir and M. Masson, Evaluation of cyclodextrin solubilization of drugs, Int. J. Pharm. 302 (2005) 18-28; DOI: org/10.1016/j.ijpharm.2005.05.042.

4. T. Loftsson, P. Jarho, M. Masson and T. Jarvinen, Cyclodextrin in drug delivery, Expert Opin. Drug Del. 2 (2005) 335-351; DOI: 10.1517/17425247.2.1.335.

5. J. A. Young, Citric acid chemical laboratory information profile, J. Chem. Ed. 80 (2003) 480.

6. W. Chen, C. K. Oh, L. J. J. Ping and P. G. Spoors, Carvedilol Monocitrate Monohydrate, U. S. Patent Appl. 2008096951, 24 April 2008 (A1).

7. P. S. Jain, G. S. Talele, S. G. Talele and S. G. Surana, Spectrophotometric determination of carvedilol from bulk and formulations, Indian J. Pharm. Sci. 67 (2005) 358-359.

8. United States Pharmacopoeia 27, National Formulary 23, USP Convention, Rockville 2004, pp. 2411-2414.

9. T. Higuchi and K. A. Connors, Phase solubility technique, Adv. Anal. Chem. Instrum. 4 (1965) 117-212.

10. X. Wen, F. Tan, Z. Jing and Z. Liu, Preparation and the study of 1:2 inclusion complex of carvedilol with $\beta$-cyclodextrin, J. Pharm. Biomed. Anal. 34 (2003) 517-523; DOI: 10.1016/SD731-7085 (03) 00576-4.

11. V. Barillaro, E. Ziemons and B. Evard, Effect of acidic ternary compounds on the formation of miconazole/cyclodextrin inclusion complexes by means of supercritical carbon dioxide, J. Pharm. Sci. 7 (2004) 378-388; DOI: 10.1021/js9703611.

12. H. Thierry and P. Geraldine, Determination of free/included piroxicam ratio in cyclodextrin complexes: comparison between UV spectrophotometry and differential scanning calorimetry, Eur. J. Pharm. Sci. 15 (2002) 347-353; DOI: 10.1016/S0928-0987(02)00018-0.

13. J. Mielcarek, Studies on inclusion complexes of felodipine with $\beta$-cyclodextrin, J. Incl. Phen. Mol. Recogn. Chem. 30 (1998) 243-252; DOI: 10.1023/A:1007960725895.

\section{$S A \check{Z} E T A K$}

\section{Ternarna kompleksacija karvedilola, $\beta$-ciklodekstrina i limunske kiseline za razvoj tableta topljivih u ustima}

VARSHA POKHARKAR, ABHISHEK KHANNA, VINOD VENKATPURWAR, SHEETAL DHAR i LEENATA MANDPE

Cilj rada bio je poboljšati topljivost i oslobađanje karvedilola stvaranjem ternarnog kompleksa s $\beta$-ciklodekstrinom i limunskom kiselinom i razvoj tableta topljivih u ustima. Takve tablete su napravljene s ciljem da se poboljša apsorpcija iz usta i izbjegne efekt prvog prolaza, što bi moglo imati za posljedicu poboljšanu bioraspoloživost. Testovi topljivosti pokazali su da $\beta$-ciklodekstrin i limunska kiselina stvaraju kompleks s karvedilolom i značajno povećavaju njegovu topljivost. Ternarna kompleksacija karvedilola 
s $\beta$-ciklodekstrinom i limunskom kiselinom provedena je fizičkim miješanjem, gnječenjem i sušenjem raspršivanjem. Pripravljeni kompleksi karakterizirani su infracrvenom spektroskopijom, diferencijalnom pretražnom kalorimetrijom, rendgenskom difraktometrijom praha, pretražnom elektronskom mikroskopijom i testovima učinkovitosti kompleksacije. Metodom sušenja raspršivanjem topljivost karvenidola povećala se 110 puta, a kompleksacija je bila najučinkovitija. Tablete pripravljene iz tog kompleksa i odgovarajućih pomoćnih tvari potpuno su se otopile unutar pet minuta. Testovi ubrzanog starenja provedeni prema ICH smjernicama pokazali su da su tablete stabilne.

Ključne riječi: karvedilol, ciklodekstrin, liminska kiselina, kompleksacija, topljivost, sušenje raspršivanjem, tablete topljive u ustima

Department of Pharmaceutics, Bharati Vidyapeeth University, Poona College of Pharmacy, Erandwane, Pune-411038, Maharashtra, India 